\title{
ANALISIS PERAN BIDAN TERHADAP KEPATUHAN PASIEN POLI IVA PUSKESMAS TEMPEL TERHADAP PROTOKOL COVID-19
}

\author{
ANALYSIS OF THE ROLE OF THE MIDWIFE ON THE COMPLIANCE OF \\ PATIENTS OF POLI IVA PUSKESMAS TEMPEL TO COVID-19 PROTOCOL
}

\author{
Nurul Soimah ${ }^{1}$ \\ ${ }^{1}$ Prodi Kebidanan DIII, Universitas Áisyiyah Yogyakarta \\ Email Correspondence : nurul_shoimah@unisayogya.ac.id
}

\begin{abstract}
Analysis Of The Role Of The Midwife On The Compliance Of Patients Of Poli Iva Puskesmas Tempel To Covid-19 Protocol. The covid-19 pandemic is an additional problem among health workers, many countries in the world have problems with a lack of health workers to uneven placement, essential services by health workers are hampered due to a lack of health workers in the community. This type of research is a qualitative quantitative research, using a situational analysis design with a case study approach. In Puskesmas midwives using structured interview guidelines and a study of documentation of the number of outpatient visits. sex road. Data collection was carried out through a study of documentation of the number of IVA health care patients who visited the poly, documentation of patient medical records, as well as electronic Whats-up media interviews with 2 midwives, 1 doctor, 1 triangulation of structural official sources at the Tempel Sleman Yogyakarta Health Center. Data analysis with data reduction, categorized into sub-theme (Sugiono, 2019), The results showed that outpatient services were carried out following SOPs, the Indonesian Ministry of Health's technical instructions, the role of midwives as implementing the Covid 19 task force from the tracing stage to the distribution of bodies detected by Covid 19. Patient compliance with health protocols was carried out with protocols strictly according to the flow of outpatients at the Kespro poly, health protocol discipline consisting of wearing masks, washing hands, maintaining distance, the results obtained with good criteria.
\end{abstract}

Keywords: the Role of the Midwife. Covid-19 Protocol

\begin{abstract}
Abstrak : Analisis Peran Bidan Terhadap Kepatuhan Pasien Poli Iva Puskesmas Tempel Terhadap Protokol Covid-19. Pandemic covid-19 menjadi permasalahan tambahan dikalangan tenaga kesehatan yang, Banyak negara didunia yang mengalami permasalahna kurangnya tenaga kesehatan hingga penempatan yang tidak merata, layanan esensial oleh tenaga kesehatan menjadi terhambat karena kurangnya tenaga kesehatan dimasyarakat. Jenis penelitian ini adalah penelitian Kuantitatif kualitatif, menggunakan desain Analitik situasi dengan pendekatan studi kasus.pada bidan Puskesmas dengan menggunakan pedoman wawancara terstruktur dan studi dokumentasi jumlah kunjungan pasien rawat jalan kespro. Pengambilan data dilakukan melalui studi dokumentasi jumlah pasien kespro IVA yang berkunjung ke poli, dokumentasi rekam medis pasien, serta wawancara elektronik media Whats up pada 2 bidan, 1 dokter, 1 triangulasi sumber pejabat structural Puskesmas Tempel Sleman Yogyakarta Analisa data dengan reduksi data, dikategorikan menjadi sub tema (sugiono,2019), Didapatkan hasil bahwa pelayanan rawat jalan dilaksanakan mengikuti SOP, Petunjuk tehnis Kemenkes RI, peran bidan berperan sebagai pelaksana gugus tugas Covid 19 dari tahap tracing sampai pemusalaran jenazah terdeteksi covid 19.kepatuhan pasien terhadap protocol kesehatan terlaksana dengan protocol ketat sesuai alur pasien rawat jalan poli Kespro, displin prokol kesehatan yang terdisi dari memakai masker, cuci tangan, menjaga jarak didapatkan hasil dengan kriteria baik.
\end{abstract}

Kata Kunci: Peran Bidan, Protokol Covid-19, IVA 
Vol 11 No 1 Januari 2022 | Page 153-164

\section{PENDAHULUAN}

Pandemi COVID-19 telah banyak berpengaruh terhadap berbagai sendi kehidupan. Jurnal penelitian tentang pengaruh COVID-19 dipaparkan diantaranya dijelaskan bahaw situasi pandemi covid-19 berpengaruh terhadap dunia ekonomi (Fernandes, 2020), Pendidikan (Abidah et al., 2020; Cao et al., 2020), pariwisata (Gössling et al., 2020), tak terkecuali kehidupan keagamaan. Berdasarkan data sebaran covid-19 yang daimbil dari berita Tribun Jogja (2020) dipaparkan tentang sebaran covid Di Indonesia didapatkan tanggal 12 September 2020 didapatkan Data terakhir yang dilansir dari BPNB menyatakan kasus terkonfirmasi positif corona telah mencapai angka 210.940 pasien, Jumlah ini mengalami penambahan sebanyak 3.737 kasus, bila dibanding data terakhir pada hari sebelumnya, kabar gembiranya adalah angka kesembuhan pasien covid-19 di Indonesia juga dilaporkan terus bertambah. angka kesembuhan telah mencapai 150.217 orang. korban meninggal terkonfirmasi positif virus corona adalah sebesar 8.544 orang. Sebaran covid 19 Jawa Tengah menempati urutan ke dari total angka di Indonesia, didapatkan Kasus Baru: 566 orang, Sembuh: 10.817 orang, Meninggal Dunia: 1.129 orang, Terkonfirmasi: 17.074 orang.

Permaslahan pandemic menjadi permasalahan tambahan dikalangan tenaga kesehatan yang komplek,Banyak negara didunia yang mengalami permasalahna kurangnya tenaga kesehatan hingga penempatan yang tidak merata, layanan esensial oleh tenaga kesehatan menjadi terhambat karena kebutuhan kesehatan masyarakat yang meningkat karena pandemic yang menyerang seluruh lapisan masyarakat, termasuk tenaga kesehatan sendiri, permasalahan kurangnya tenaga menjadi bertambah berat seiring dengan adanya kejadian paparan yang menimpa tenaga kesehatan dan harus menjalani karantina srta pengobatan yang berujung pada beban kapasitas layanan esensial. Hal tersebut berdampak pada perempuan karena mayoritas tenaga kesehatan di Indonesia adalah perempuan, termasuk didalamnya adalah Bidan (WHO,2020)

Dampak lebih lanjut terkait pada layanan KIA Kespro adalah terjadinya penurunan layanan, terutama pada layanan bayi dan balita (Yulia R, dkk,2021), berkaitan dengan penurunan poli rawat jalan Kespro IVA sebagai langkah deteksi dini kanker servik melalui rekomendasi WHO (2020) menekankan bahwa prioritas tata laksana deteksi dini kanker diprioritaskan pada pengobatan jika sudah terdeteksi dini dengan pertimbangan masa pandemic yang beresiko pada pajanan dan tingkat imunologi pasien. Mengacu pada permasalahan kesehatan dimasa pandemic covid-19 pedoman tata laksana pelayanan kesehatan diprioritaskan pada kaidah perundang undangan yang adil dan merata mengacu pada ketentuan Undang-Undang Nomor 36 Tahun 2009, Tentang Kesehatan disebutkan bahwa setiap kegiatan dalam upaya untuk memelihara dan meningkatkan derajat kesehatan masyarakat yang setinggi-tingginya dilaksanakan berdasarkan prinsip non diskriminatif, partisipatif, dan berkelanjutan dalam rangka pembentukan sumber daya manusia Indonesia, serta peningkatan ketahanan dan daya saing bangsa bagi pembangunan nasional".

Berkembangnya pandemic covid-19 disikapi oleh pemerintah dengan terbitnya kebijakankebijakan dasar pelaksanaan penanggulangan bencana diantaranya Kebijakan pemerintah Protokol kesehatan covid-19, Salah satu kebijakan yang merupakan kebijakan yang sangat berguna. Penanggulangan pandemic covid-19 melibatkan peran bidan Peran bidan secara paripurna dimulai sejak upaya promotip, prefentip, kuratif, rehabilitatip hingga pada seseorang mampu mengatasi dirinya sendiri. Salah satu peran bidan pada upaya promotif diatur dalam Permenkes no 585 tahun 2007 Tentang Promosi Kesehatan Di Puskesmas, Promosi kesehatan dilakukan melaui upaya pemberdayaan masyarakat secara individu, keluarga dan masyarakat. Salah satu fungsi puskesmas adalah 
mengutamakan pemeliharaan kesehatan melalui pencegahan penyakit dan promotif.peran utama bidan adalah Sebagai Advokator, edukator,fasilitator,motifator. Peran lain dari bidan dijelaskan bahwa Peran bidan adalah proses untuk mendidik dan membimbing seseorang yang sesuai dengan perkembangan alamiahnya bahkan sesuai dengan apa yang seharusnya mereka pelajari (Sarwono, 2006).Peran bidan adalah suatu tugas yang harus dilakukan oleh seseorang yang mempunyai hak dan kewajiban sesuai dengan kedudukannya di dalam anggota keluarga (Mambang, 2012).

Penanggulangan pandemic covid-19 dikalangan POLRI juga ambil peran yaitu terus mensosialisasikan protokol kesehatan dan 3M. Ada tiga disiplin protokol kesehatan yang harus dilakukan, yakni memakai masker, mencuci tangan dengan sabun dan menjaga jarak. (Riki Susanto,2020). Kebijakan pemerintah dan peran tenaga tidak bias lepad dari peran masyarakat., peran masyarakat diperlukan yang paling penting adalah tertib dan disiplin menerapkan protocol kesehatan covid-19 pada penerapan 3M, mencuci tangan dengan sabun, menjaga jarak aman, memakai masker. Peran masyarakat tersebut belum tercapai dengan baik, hal tersebut didukung dengan hasil penelitain Muhith S, dkk, (2021) hasil Penelitian menunjukkan hubungan yang signifikan antara pendidikan ( $p$ value $=0,004)$, pengetahuan $(p$ value $=0,000)$, sikap $(p$ value $=0,016)$, penyediaan sarana prasarana ( $p$ value $=0,026$ ), edukasi ( $p$ value $=0,021)$ dengan kepatuhan penerapan protokol kesehatan Covid19. Hasil analisis multivariat menunjukkan variabel yang berpengaruh terhadap kepatuhan penerapan protokol kesehatan Covid-19 adalah variabel sikap dengan Odd Ratio 0,296 ( $p$ value $=0,039$ ).

\section{METODE}

Jenis penelitian ini adalah kuantitatif mengamdil data jumlah kunjungan poli kespro, kualitatif studi kasus dengan desain Indepth Interviews (IDIs atau wawancara mendalam) menggunakan pedoman wawancara terstruktur untuk dapat menggali, mengetahui pemahaman yang utuh tentang peran bidan, pada kebijakan pemerintah Tentang penerapan disiplin hukum protocok covid 19 pada pasien.kunjungan KIA ,Kuantitatif dengan mengambil data kunjungan pasien ke poli kespro untuk mengetahui penerapan displin protokol-19. Penelitian menggunakan atau menggambarkan hasil dalam bentuk narasi kalimat dan tabel distribusi frekuensi( Soegiyono, 2019) yaitu penelitian yang menggali bagaimana dan mengapa fenomena terjadi serta melakukan analisis dinamika hubungan antara tingkat peran bidan terhadap upaya pencegahan penyebaran covid 19 pada pasien kunjungan poli kespro IVA di wilayah kerja Puskesmas Tempel. Pendekatan waktu yang digunakan pada penelitian ini adalah pendekatan waktu cross sectional, yaitu pengambilan data yang dilakukan dalam waktu yang bersamaan.(Suharsimi-Arikunto, 2010). Proses pengambilan data berlangsung 1 hari pada bulan Agustus 2021.melalui media teleconference media whats up pada 4 informan.

\section{Informan / Partisipan penelitian, Responden}

1. Informan diambil melalui wawancara telepon dengan media whatsup video dengan metode Indepth Interviews (IDIs) terstruktur pada bidan di ruang poli KIA . Spesifikasi informan sejumlah 2 Bidan 1 Kepala Diklat Puskesmas Tempel.

2. Tri angulasi sumber diambil Informan / Responden 1 orang dokter/pejabat struktural Puskesmas Responden diambil secara total sampling didapatkan sejumlah 64, dipilih ssesuai kriteria inklusi yaitu data pasien lengkap, diadapatkan sejumlah 45 responden

https://ejournal.umpri.ac.id/index.php/JIK $1 \mathbf{1 5 5}$ 
Vol 11 No 1 Januari 2022 | Page 153-164

\section{HASIL}

Puskesmas Tempel 1 dalam pelaksaan pelayanan pasien selama pandemic covid 19 telah mengacu pada Juknis Pelaksaan Pelayanan Puskesmas dimasa Pandemi kemenkes RI dan SOP alur pelayanan pasien dimasa pabdemi covid 19, Pelaksanaan penelitian berlangsung selama kurun waktu bulan Juli-Agustus 2021, wawancara terlaksana melalui media telepon pada 2 bidan, 1 orang dokter, 1 orang staf diklat, pengambilan data sukender dilakukan secara online dengan pengiriman berkas data, proses ini dilakukakukan sesuai dengan kesepakatan dengan pihak Puskesmas karena masih dalam masa puncak gelombang pendemi covid 19.

Tabel 1. Karakteristik Informan penelitian Analisis Yuridis Peran Bidan Terhadap Kepatuhan Pasien Pada Penerapan Displin Hukum Protokol Covid 19 Pada Pasien Yang Berkunjung Ke Poli Kespro Puskesmas Tempel

\begin{tabular}{llll}
\hline No & Umur & Informan & Keterangan \\
\hline $\mathbf{1}$ & 38 & Bidan & Informan Primer 1 (IF 1) \\
$\mathbf{2}$ & 50 & Bidan & Informan Primer 2 (IF2) \\
$\mathbf{3}$ & 39 & Dokter & Informan sumber data sekunder \\
$\mathbf{4}$ & 50 & Staf & Triangulasi sumber \\
\hline \multicolumn{3}{l}{ Sumber data primer 2021 }
\end{tabular}

Tabel 2. Hasil Wawancara Mendalam

\begin{tabular}{|c|c|c|}
\hline No & Tema & Hasil wawancara \\
\hline 1 & $\begin{array}{l}\text { Peran Bidan pada } \\
\text { pelaksanaan } \\
\text { program kerja poli } \\
\text { KIA dan Kespro }\end{array}$ & $\begin{array}{l}\text { Program KIA yang bisa jalan selama pandemic Peran sentral bidan di masa } \\
\text { pandemic. Gugus tugas covid berlaku bagi semua bidan, bidan desa } \\
\text { bertanggung jawab penuh pada tracing wilayah ketika didapatkan kasus covid, } \\
\text { sampai kepada rujukan dan evakusai, kasus kematian pemusalaran jenazah. } \\
\text { Gugus tugas sekarang pasca puncak kasus paparan covid } 19 \text { peran utama bidan } \\
\text { sebagai vaksinator yang diatur agar poli rawat jalan dan ranap tetap jalan. }\end{array}$ \\
\hline 2 & $\begin{array}{lr}\text { Kebijakan } & \text { Disiplin } \\
\text { Hukum } & \text { Pasien } \\
\text { rawat } & \text { Jalan } \\
\text { terhadap } & \text { Protokol } \\
\text { kesehatan covid } 19\end{array}$ & $\begin{array}{l}\text { a. Surat Edaran Menteri Desa, PDT, dan Transmigrasi Nomor } 8 \text { Tahun } 2020 \\
\text { tentang Desa Tanggap Covid-19 dan Penegasan Padat Karya Tunai Desa } \\
\text { b. Keputusan Presiden Nomor } 11 \text { Tahun } 2020 \text { tentang Penetapan Kedaruratan } \\
\text { Kesehatan Masyarakat Covid-19 } \\
\text { c. SOP Pendaftaran Pasien Dimasa Pnademi covid } 19 \\
\text { d. Juknis Alur Pelayanan rawat jalan Puskesmas selama masa pandemic } \\
\text { kemenkes RI }\end{array}$ \\
\hline 3 & Alur Penanganan & $\begin{array}{l}\text { Pembatasan jam layanan KIA hanya dikurangi } 1 \text { jam sesuai surat edaran dinkes } \\
\text { sleman } \\
\text { upaya pelaksanaan prokes pasien rawat jalan dilaksanakan sesuai SOP pasien } \\
\text { rawat jalan, untuk KIA bagi ibu hamil dengan gejala ispa diskrening di poli } \\
\text { ispa, bidan datang memeriksa dengan pemakaian APD level } 3 \text {. } \\
\text { Mekainsme layanan pasien selama pandemic pengaturan layanan persalinan, } \\
\text { persalinan dilakukan dengan protokol skrening poli ispa, petugas menggunakan } \\
\text { APD level } 2 \\
\text { Pengaturan layanan KIA dan kespro dijalankan , untuk deteksi HIV, hepatitis, } \\
\text { IVA selalu dilakukan ketika pasien masuk, yaitu skrening HIV/Aids dan PMS, } \\
\text { hanya saja karena pandemic pasien menurun. APD yang digunakan adalah level } \\
2 \text { jika tidak didapatkan tanda gejala covid }\end{array}$ \\
\hline 4 & $\begin{array}{l}\text { Penerapan } \\
\text { Covid } 19 \text { pasiplin } \\
\text { rawat jalan poli } \\
\text { kespro }\end{array}$ & $\begin{array}{l}\text { Pasien memasuki area puskesmas dari pintu masuk sudah dijaga satpam bahwa } \\
\text { pasien wajib melakukan cuci tangan dan memakai masker, duduk menempati } \\
\text { kursi antrean sesuai ketersdiaan kursi yang sudah di atur dengan aturan jaga } \\
\text { jarak, secara tata laur paisen masuk dan selama menunggu giliran sudah sesuai }\end{array}$ \\
\hline
\end{tabular}


dengan protocol kesehatan, hanya saja untuk tehnik cuci tangan dan memakai masker yang terkadang masih harus diingatkan oleh petugas, namun ketika memasuki ruangn periksa dan skrening bidan memberlkuakan aturan ketat harus memakai masker yang benar dan memastikan pasien sudah cuci tangan,

Setiap pasien yang sudah siap diperiksa akan kembali ditanyakan apakah sudah cuci tangan atau belum, jika sudah tapi belum benar pasien harus cuci tangan dengan handsanytizer yang tersedia diruangan kerana Setiap ruang periksa tersedia juga handsanityzer yang bisa digunakan untuk pasien

Sumber data primer wawancara 2021

Tabel 3. Distribusi Frekuensi Analisis Yuridis Peran Bidan Terhadap Kepatuhan Pasien Pada Penerapan Displin Hukum Protokol Covid 19 Pada Pasien Yang Berkunjung Ke Poli Kespro Puskesmas Tempel

\begin{tabular}{|c|c|c|c|c|c|}
\hline \multicolumn{2}{|c|}{ Cuci tangan } & Frequency & Percent & $\begin{array}{c}\text { Valid } \\
\text { Percent }\end{array}$ & $\begin{array}{c}\text { Cumulative } \\
\text { Percent }\end{array}$ \\
\hline \multirow[t]{4}{*}{ Valid } & Kurang & 7 & 15.6 & 15.6 & 15.6 \\
\hline & Sedang & 20 & 44.4 & 44.4 & 60.0 \\
\hline & Baik & 18 & 40.0 & 40.0 & 100.0 \\
\hline & Total & 45 & 100.0 & 100.0 & \\
\hline \multicolumn{6}{|c|}{ Memakai masker } \\
\hline \multirow[t]{9}{*}{ Valid } & Kurang & 6 & 13.3 & 13.3 & 13.3 \\
\hline & Sedang & 7 & 15.6 & 15.6 & 28.9 \\
\hline & Baik & 32 & 71.1 & 71.1 & 100.0 \\
\hline & Total & 45 & 100.0 & 100.0 & \\
\hline & Jaga jaral & & & & \\
\hline & Kurang & 13 & 28.9 & 28.9 & 28.9 \\
\hline & Sdang & 4 & 8.9 & 8.9 & 37.8 \\
\hline & Baik & 28 & 62.2 & 62.2 & 100.0 \\
\hline & Total & 45 & 100.0 & 100.0 & \\
\hline
\end{tabular}

Data distribusi frekunesi dari 45 responden didapatkan bahwa cuci tangan menunjkkan hasil tertinggi pada kriteria sedang sejumlah 20 orang (44\%), terendah pada kategori kurang sejumlah 7 orang ( $15 \%)$, pemakaian masker tertinggi pada kriteria baik sejumlah 32 orang $(71,1 \%)$, terendah pada krieria kurang sejumlah 6 orang (13,3\%), Menjaga jarak tertinggi pada kriteria baik sejumlah 28 orang, terendah pada kriteria kurang sejumlah 13 orang $(28,9 \%)$.

Tabel 4. Distribusi silang Analisis Yuridis Peran Bidan Terhadap Kepatuhan Pasien Pada Penerapan Displin Hukum Protokol Covid 19 Pada Pasien Yang Berkunjung Ke Poli Kespro Puskesmas Tempel

\begin{tabular}{lllllll}
\hline & Cuci tangan & $\begin{array}{c}\text { Memakai } \\
\text { masker }\end{array}$ & Jaga jarak & n & \\
\hline Cumulative variabel & Valid Percent & Valid Percent & $\begin{array}{c}\text { Valid } \\
\text { Percent }\end{array}$ & $\begin{array}{c}\text { Cumulative } \\
\text { Percent }\end{array}$ \\
\hline Valid & Kurang & $7(15.6)$ & $6(13.3)$ & $13(28.9$ & & 19,2 \\
& & & & $4(8.9)$ & 26 & \\
& Sdang & $20(44.4)$ & $7(15.6)$ & $28(62.2)$ & 78 & 57.7 \\
& Baik & $18(40.0$ & $32(71.1)$ & $45(100)$ & 135 & 100 \\
\hline
\end{tabular}


Vol 11 No 1 Januari 2022 | Page 153-164

Hasil olah data institusi total sampling 65 orang, inklusi terpenuhi 45 pasien.hasil tertinggi didapatkan pada kriteria baik sejumlah 57,7\%, terendah pada kriteria kurang sejumlah 19,2\%

\section{PEMBAHASAN}

\section{Peran Bidan Pada Promosi Protokol Covid 19 Bagi Pasien Rawat Jalan Poli Kespro Puskesmas}

Mengacu pada hasul wawancara dan Analisa data sekunder yang didapatkan bahwa Sesuai dengan peran bidan dalam memberikan pelayanan selama pandemic covid 19 dan sesuai dengan peran bidan pada upaya promosi kesehatan di puskesmas tempel adalah melaksanakan gugus tugas percepatan penanganan covid 19, dimulai dengan layanan traccing sampai pada pemusalaran jenazah terdeksi covid 19 tanpa memandang apakah itu pasien kebidanan atau pasien umum, sesuai dengan peran bidan yang tertuang pada ketentuan perudang undangan didalam Undang-Undang No 4 tahun 2019 Tentang kebidanan pasal 46 yang menyebutkan bahwa "dalam menyelenggarakan praktik kebidanan, bidan memberikan pelayanan meliputi pelayanan kesehatan ibu, pelayanan kesehatan anak,pelayanan kesehatan reproduksi perempuan dan keluarga berencana serta pelaksanaan tugas berdasarkan pelimpahan wewenang dan/atau pelaksaan tugas dalam keadaan keterbatasan tertentu"

Sesuai dengan hasil dan ketentuan perundangan jika dianalogkan dengan peran bidan dimasa pandemic ini menjukkan adanya kesesuaian antara keduanya, hal tersebut menunjukkan bahwa upaya percepatan penanganan covid 19 terlaksana secara sinergi antara tugas dan peran bidan pada setiap lini pelayanan, sekaligus telah menjalankan peran pelaksana tugas dalam keadaan tertentu, dalam hal ini tugas tertentu darurat pandemic covid 19. Jurnal penelitian Agustin, Dewi dan Febriana (2021) di Bandar Lampung menujukkan dari 106 responden bahwa peran tenaga kesehatan yang tidak patuh sejumlah 52 orang, yang patuh sejumlah 36 orang, hasil uji statistic menujukkan terdapat hubungan antara peran tenaga kesehatan dengan kepatuhan pasien rawat jalan melakuksanakan disiplin protocol kesehatan covid 19, sesuai dengan data jurnal tersebut memberikan gambaran yang lebih luas bahwa pelaksanaan disiplin protocol covid 19 pada pasien yang datang berkunjung ke fasilitas kesehatan puskesmas masih menjadi permasalahan bersama di Indonesia yang masih perlu terus disikapi sebagai upaya peningkatan derajat kesehatan secara berkesinambungan bagi bidan dalam menjalankan peran dan fungsinya sebagai salah satu tenaga kesehatan.

Mengacu pada pelaksanaan protocol covid 19 yang didapatkan dari data kunjungan pasien yang menujukkan secara global dari perilaku displin prokol kesehatan covid 19 dari distribusi silang menunjukkan total angka pada 45 responden kategori tertinggi pada perilaku baik sejumlah 57,7\%, hasil ini menujukkan bahwa peran bidan pada upaya promosi langsung pada saat pasien berkujung periksa masih diperlukan agar terus mempromosikan dan mendidik masyarakat agar terus menegakkan protocol ketat sebagai syarat pelayanan pasien. Dipaparkan oleh Informan Primer 1(IF 1) tentang peran bidan "Peran sentral bidan di masa pandemic. Gugus tugas covid berlaku bagi semua bidan, bidan desa bertanggung jawab penuh pada tracing wilayah ketika didapatkan kasus covid, sampai kepada rujukan dan evakusai, kasus kematian pemusalaran jenazah.ini yang kadang kami rasakan berat bu, karena bidan harus siap 24 jam dan pada jam dinas juga harus tetap menjalankan peran dan fungsinya pada pelayanan agar semua program kerja puskesmas juga tetap jalan.

Berbeda dengan pemaparan yang disampaikan oleh Informan Primer 1(IF 2) menjelaskan "bahwa berkaitan dengan peran bidan ya kami para bidan menjalankan Gugus tugas 
sekarang pasca puncak kasus paparan covid 19 peran utama bidan sebagai vaksinator yang diatur agar poli rawat jalan dan ranap tetap jalan.

Mengacu pada hasil tersebut jika di tinjau dari aspek peran bidan secara holistic bahwa tugas yang dijalankan menunjukkan bahwa bidan telah menjalankan pelaynana kebidanan yang bermutu dan berkesinambungan dengan mengedepankan pemahaman tentang falsafah, kode etik, dan regulasi yang berkaitan dengan praktik kebidanan, Dijelaskan dalam Keprmenkes No 320, Tahun 2020 tentang Standar Profesi Bidan disebutkan dalam Pendahuluan bahwa "masyarakat mengharapkan Bidan yang ramah, terampil dan tanggap di bidangnya". Mengacu dari hasil wawancara yang dipaparkan oleh (IP 1 dan 2) tersebut adalah merupakan peran bidan yang dijalankan sesuai petunjuk tehnis kesehatan lingkungan bahwa upaya yang harus dilaksanakan adalah melakukan Konseling dimasyarakat sampai dengan traccing pasien di masyarakat yang terdedeksi atau kemungkinan gejala mengarah ke paparan covid 19 , tugas ini sebagai tugas tambahan yang harus dilaksanakan selain tugas pokoknya sebagai bidan poliklinik kesehatan reproduksi dan KIA

\section{Analisis Kebijakan Peran Bidan Dan Kebijakan Disiplin Hukum Pasien rawat Jalan terhadap Protokol kesehatan covid 19 di poli Kespro}

Sesuai dengan yang disampaikan oleh Wibowo B (2020) bahwa Peran Bidan Peskesmas merupakan salah satu bagian dari peran pelaksanan Fasilitias Kesehatan Tingkat Pertama (FKTP) pada pandemi COVID-19, peran ini sebagai bentuk upaya prevent, deteksi serta respon yang penting pada upaya pencapaian langkah pencegahan dan pengendalian penyebaran covid 19

A. Promosi Kesehatan

Upaya promosi ynag dapat terlaksana dimasa pandemic seperti yang disampaikan oleh (IP 1) "karena dengasn keterbatasan situasi pandemic maka kami bisanya ya melakukan sesuai juknis kemenkes bu, yang penting ada komunikasi dan jalinan kemitraan dengan RT, RW, toma, toga, kader leat komunikasi WA dan telpon, karena merekalah yang bias memantau langsung kondisi lingkungannya, mana dan siapa saja yang patuh protocol dan yang tidak, yang sakit dan yang sehat dilingkungannya, yang penting kita mengupayakan agar masyarakat saling bisa mengingatkan dan membantu tetangga yang kiranya perlu, tapi kita juga wanti wanti memesan agar jika terpaksa ada warga yang sakit ya lapor dulu ke puskesmas untuk segera ditindak lanjuti, tidak kemudian mereka menolong langsung tanpa tahu apa sakitnya. Dan tokoh2 masyarakat ini yang kita pesen juga harus bias jadi contoh praktik taat protocol kesehatan."

Jawaban tersebut menggambarkan bahwa sesuai dengan petunjuk teknis kemenkes 2020 memang telah dilaksanakan pada pelayanan puskesmas Tempel tentang pelaksaan upaya promosi kesehatan, Yaitu Melakukan kemitraan untuk mendapat dukungan dan menjalin kerjasama kegiatan Puskesmas dalam pencegahan COVID-19 di wilayah kerja Puskesmas. Sasaran kemitraan diantaranya gugus tugas tingkat RW atau Relawan Desa, Ormas, TP PKK, swasta, SBH, tokoh masyarakat, tokoh agama dan mitra potensial lainnya ( Kemnkes, 2020)

Peran bidan sebagai salah satu tenaga kesehatan yang memiliki peranan strategis sebagai petugas langsung dalam penanganan covid 19 9Li et al, dalam Afandi,Handayani dan Zaini, 2021). Mengacu pada hasil dan beberapa tinjauan yang ada menujukkan bahwa pelaksaan promosi kesehatan di Puskesmas Tempel selama masa pandemic dapat berjalan sesuai situasi dan kondisi .Jalinan kerja sama lintas sector menjadi upaya yang telah dilaksanakan agar program berjalan.

https://ejournal.umpri.ac.id/index.php/JIK 159 
Vol 11 No 1 Januari 2022 | Page 153-164

Langkah promosi kesehatan yang dilaksanakan di poli rawat jalan kesehatan reproduksi seperti dipaparkan oleh ( IP 1)

"Layanan rawat Jalan untuk deteksi HIV, hepatitis, IVA selalu dilakukan ketika pasien masuk skrening HIV/Aids dan PMS, hanya saja karena pandemic pasien menurun. APD level 2 jika tidak didapatkan tanda gejala covid.19 Selain penggunaan APD oleh petugas, puskesmas juga menerapkan kebijakan untuk pelaksaan protocol kesehatan masyarakat ketika pasien dating ke puskesmas, dijelaskan oleh (IS ) bahwa "setiap pasien harus sesuai dengan prokes yang ada yaitu masuk Kawasan PKM dengan cuci tangan di depan pintu masuk, memakai masker, menjaga jarak aman ketika harus antri,masuk ruang skrining untuk kelayakan pemeriksaan, kemudian setelah lolos skrening baru pasien masuk ruang periksa sesuai alasan dating ke puskesmas. Jurnal pengabdian masyarakat Rosali M, 2021, menerapkan protokol kesehatan secara ketat mengingat kegiatan dilaksanakan pada masa pandemi Covid19 Physical distancing juga diterapkan selama kegiatan berlangsung, Sebelum memasuki Poliklinik seluruh tim pengabdian dan peserta wajib mencuci tangan dan menggunakan masker selama kegiatan berlangsung. Seluruh tim medis yang bertugas juga dilengkapi dengan alat eplindung diri (APD)

B. Startegi pencapaian program

Hasil wawancara yang disampaikan oleh (IP 1 didukung oleh Informan sekunder (IS) dijelaskan bahwa

"Strategi dilaksanakan mengikuti ketentuan kebijakan yang diterbitkan kemenkes pusat dan Dinkes profinsi serta kabupaten, hal tersebut mengungat bahwa penanganan dan pelaksanaan program karena masa daurat pandemic maka ada keterbatasan pelaksaan sesuai dengan alur penanganan yang aman.

Menurut Emi Nurjasmi (2020) memaparkan bahwa pelayanan KIA Kespro dilaksanakan sesuai dengan prinsip Penyelenggaraan Pelayanan Kebidanan Pada Masa Pandemi Covid-19 yang meliputi langkah pra pelayanan, pelaksanaan, serta pasca pelayanan, tahapan tersebut harus dilaksanakan untuk tahap konsultasi dan konseling awala dilakukan secara online, jika memang diperlukan langkah pemeriksaan maka antara pasien dan bidan membuiat kesepakatan perjanjian untuk pemeriksaan melalui media telpon atau WA,pada tahap ini diperlukan pengkajian secara komprehenship sesuai standar skrining yang harus diwaspadai adanya emungkinan gejala mengarah ke tanda covid -19, pastikan tidak sedang dalam masa isoman.

Informan (IP2) menjelaskan bahwa cakupan KIA dan Kespro dengan sendirinya mengalami penurunan karena situasi pandemic dan pasien beralih ke PMB. Hasil tersebut menujukkan bahwa kondisi penurunan pasien kunjungan Poli Kespro IVA menjadi sesuai dengan rekomendasi WHO bahwa program kerja Puskesmas pada upaya skrining kanker serviks diperlukan adanya modifikasi dan pertimbangan penundaan program skrining ditingkat fasilitas kesehatan, promosi skrining lebih diarahkan ke fasilitas mandiri berbasis rumah praktik secara kolektif dengan tempatyang memungkinkan, promosi dan komunikasi lebih ditekankan dengan fasilitas online , jika hasil diagnostic positif, segera menyusun perencanaan dan langkah rujukan tindak lanjut (WHO,2020).

(IS) menjelaskan bahwa upaya penanggulangan kasus covid yang terjadi di masyarakat, yang memegang peranan utama adalah bidan yang memiliki tugas pemantauan wilayah setempat (PWS) KIA, bidan PWS KIA memiliki tanggung jawab pada penangannan pasien terdeteksi positif 
covid dimaulai dari proses tracing, pengawasan dan pemantauan selama dirawat maupun selama menjalani isolasi mandiri (ISOMAN), permasalah tenaga inilah yang paling terasa menjadi kendala pengaturan alur penangannan program kegiatan.

C. Kebijakan tata kelola pasien rawat jalan

Paparan hasil wawancara (IP 1) menjelaskan bahwa sekarang ada pembatasan jam layanan KIA kespro hanya dikurangi 1 jam sesuai surat edaran dinkes sleman,

Menurut Komimfo, 2021, dijelaskan bahwa Akses pelayanan kebidanan diera pandemi covid-19 mengalami perubahan-faskes primer/PMB membatasi pelayanan. Tingginya kasus penderita covid-19 yang dirawat di RS rujukan berpengaruh terhadap penanganan pelayanan rujukan maternal dan neonatal," Sesuai dengan hasil dan paparan komimfo jika dianalogkan dengan tata kelola pasien dimasa pandemic memiliki makna yang sama bahwa alur penangan pasien di FKTP dimasa pandemic terdapat keterbatasan, hal tersebut dilaksanakan sesuai dengan petunjuk tehnis kemenkes RI tahun 2020.

Kebijakan tata kelola yang lain menyangkut langkah prefensi petugas dalam memberikan pelayanan seperti dipaparkan oleh (IP 2) juga menjawab bahwa penggunaan APD yang sesuai rasanya sangat tidak nyaman dirasakan tetapi kami harus menepis rasa tersebut dengan keyakinan bahwa hal tersebut menjadi penguat hati kita untuk tetap bekerja meskipun dalam hati ada rasa khawatir kalau tertular,kita mantap bu kalau APD yang kita gunakan bisa melindungi kita selain kita pasrah mohon doá dari Allah agar senantiasa dijaga, karena kita tahunya kan ilmu bahwa APD bias membantu mengurangi penularan kan?"Kita ikut SOP pasien rawat jalan yang sudah ada saja bu yang aman, untuk KIA bagi ibu hamil dengan gejala ispa diskrening di poli ispa, bidan datang memriksa dengan APD level 3. Selain itu juga ada SOP yang mengatur tentang langkah langkah pasien memasuki area Puskesmas selama masa pandemic terutama pada langkap penerapan disiplin hokum protocol lesehatan seperti cuci tangan, memakai masker, dan jaga jarak.

Paparan jawaban tersebut menggambarkan bahwa pengetahuan dan perilaku bidan telah menjalankan tugas dan tanggung jawabnya . hal tersbut juga menunjukkan bahwa pelaksaan gugus tugas covid 19 oleh bidan menjukkan bahwa bidan tetap ambil peranan sesuai dengan ketentuan UU no 4 Tahun 2019 Tentang Kebidanan pasal 47 yang menyebutkan bahwa ; "Bidan dapat berperan sebagai pemberi pelayanan kebidanan, pengelola pelayanan kebidanan, penyuluh dan konselor, pendidik, pembimbing, dan fasilitator klinik, penggerak peran serta masyarakat dan pemberdayaan perempuan dan/atau peneliti dalam penyelenggaraan praktik kebidanan. Penelitian di Jember tentang Penggunaan APD oleh tenaga kesehatan menunjukkan bahwa menunjukkan bahwa pengetahuan tenaga kesehatan yang baik dengan perilaku penggunaan alat pelindung diri sebanyak 91 responden $(71.7 \%)$, dan pengetahuan tenaga kesehatan yang sedang dengan perilaku penggunaan alat pelindung diri sebanyak 17 responden (13.4\%). Berdasarkan uji statistik terdapat hubungan yang bermakna (signifikan) antara pengetahuan tenaga kesehatan dengan perilaku penggunaan alat pelindung diri di masa pandemi Covid-19 di RSD Balung ( Afandi, Hanifah dan Zaini, 2021).

Berdasarkan hasil, jika dianalogkan dengan ketentuan perundang undangan dan jurnal tersebut diatas menggambarkan bahwa ketentuan perundang undangan telah dilaksanakan oleh bidan sesuai pasal 47 tersbut, adapun berdasarkan jurnal menjukkan bahwa pengetahuan 
mempengaruhi sikap. Peran bidan Puskesmas tempel pada pelaksanaan tugas rawat jalan poli kespro telah dilaksanakan sesuai pengetahuan yang dimiliki dan perilaku pencegahan yang dilaksanakan dengan baik.

D. Kendala pelaksanaan program Rawat jalan Kespro IVA

Kendala pelaksanaan program seperti dipaparkan oleh (IP 1) bahwa "ada Pembatasan jam layanan KIA, minimnya petugas bidan, selama tahun 2020 ada 3 bidan yang telah purna tugas dari sebelumnya 11 bidan, sisanya tinggal 8 bidan yang harus bisa mengatur alur pelayanan antara rawat jalan, rawat inap yang pelaksaannya disesuaikan dengan protocol penanganan pasien di masa pandemic. Pengaturan jobdis bidan menjadi tanggung jawab bersama mengingat keterbatasan tenaga, dan situasi tanggap darurat covid 19 sehingga pelaksanaanya menjadi tetap dibagi agar program yang sesuai dan ada kebijakannya tetap jalan dengan mengacu pada kebijakan khusus selama masa pandemic, maslah lain adalah karena tenaga bidan yang ada juga 2 diantaranya sudah memasuki masa persiapan pensiun, sehingga pelaksaan tugasnya dibedakan dengan bidan yang muda.kalau dirasakan ya Lelah bu dalam tugas saat ini, tapi karena keadaannya memang demikian.

Selama masa pandemic untuk kunjungan kespro tercatat 65 pasien tetapi hanya ada sekitar 11 yang bersedia dilakukan IVA dimasa normal saja yang namanya pasien disarankan untuk IVA itu sulit bu, kadang kiat seperti memaksa karena melihat tanda dan gejalanya, kalau sekarang karena pandemic memang benar benar sepi, untuk IVA kita lakukan sesuai dengan protocol kesehatan yang diatur dalam juknis pelayanan puskesmas dan SOP

Berdasarkan hasil penelitian didapatkan adanya kendala tenaga, permasalah tenaga bidan adalah menjadi bagian dari tanggung jawab puskesmas dan dinas kesehatan, hal tersebut dijelaskan oleh Triangualsi sumber yang menyatakan bahwa

"masalah tenaga sebenarnya sudah ada sejak tahun 2018 sebelum pandemic, bertambah lagi kendalanya karena sampai saat ini belum ada penambahan enaga bidan

Emi N (2020) memaparkan tentang pentingnya Keselamatan bidan serta pasien harus dilindungi, diperlukan penyesuaian pelayanan agar terhindar dari penularan. Mengacu pada hasil dan paparan ahli jika dianalogkan dengan mekanisme kerja bidan yang masih terdapat pola kerja tumpeng tindih antara tugas poliklinik dan gugus tugas covid 19 menjadi rentan dengan resiko keselamatan bidan, keterbatasan tenaga yang minim menjadi factor pemicu kelelahan petugas yang menjadi beresiko pada melemahnya daya tahan tubuh, kendala ini dapat menjadi kendala yang berantai pada ketercapaian program poli rawat jalan. Berdasarkan hasil yang didapatkan tentang penurunan jumlah kunjungan kespro dateksi dini IVA jika dicermati dari segi pandemic dapat dirasionalisasi memang karena keterbatasan situasi, namun jika dicermati dari kendala tenaga bidan juga mbisa menjadi masalah berkelanjutan yang dapat menghambat pelaksanaan program. Hasil ini berbeda dengan Hasil penelitianRosali (2021) di BukittInggi menjujkkan bahwa, dari komponen input pelaksanaan program deteksi dini kanker serviks yaitu belum adanya dana khusus, dari segi komponen proses yaitu masih kurangnya sosialisasi yang diberikan kepada masyarakat, dan komponen output pelaksanaan program deteksi dini kanker serviks belum sesuai dengan yang diharapkan karena kurangnya partisipasi masyarakat untuk melakukan pemeriksaan 
Vol 11 No 1 Januari 2022 | Page 153-164

dan masih ada bidan yang belum mengerti mengenai pemeriksaan IVA. Kesimpulan dari penelitian pelaksanaan program deteksi dini kanker serviks dengan Metode IVA belum terlaksana dengan maksimal. Mengacu pada hasil dan jurnal terdapat perbedaan kendala cakupan IVA, secara keseluruhan masih didapatkan kendala baik dari segi dana, tenaga dan kesadaran masyarakat tentang arti pentingnya periksa.

\section{SIMPULAN}

Peran bidan pada upaya penerapan disiplin hukum protocol kesehatan covid-19 3M pada pasien rawat jalan didapatkan hasil baik, peran bidan pada masa pandemic didapatkan peran ganda karena kendala kurangnya tenaga bidan, bidan berperan sebagai pelaksana poliklinik, pelaksana gugus tugas covid-19 sekaligus sebagai vaksinator dengan jumlah keterbatasan tenaga yang tersedia. Startegi pencapaian program kerja selama pandemic covid-19 mengacu pada Petujukn tehnis pelaksanaan layanan pasien rawat jalan puskesmas, SOP Alur pelayanan pasien rawat jalan dan Sesuai dengan perundang uandangan yang berlaku,. Kendala terkait penurunan jumlah kunjungan dikarenakan situasi pandemic covid-19 dan edaran WHO terkait system pelayanan deteksi dini kanker serviks IVA.

\section{SARAN}

Diperlukan segera untuk pemenuhan jumlah tenaga Bidan Puskesmas agar anatar program kerja, beban kerja dan ketersedian tenaga memadai.

\section{DAFTAR PUSTAKA}

Alfridho Ade Permana,Susanto R, (2020), Disiplin Protokol Kesehatan Kunci Utama Kendalikan Penyebaran Covid-19 https://www.bengkuluinteraktif.com/disiplin-protokol-kesehatan-kunciutama-kendalikan-penyebaran-covid-19

Afandi A, Handayani LT, Zaini M (2021), Hubungan Pengetahuan Dan Sikap Tenaga Kesehatan Dengan Perilaku Penggunaan Alat Pelindung Diri Di Masa Pandemi Covid 19 Di RSD Balung, Httprepository.Unmuhjember.Ac.Id8448121.\%2520artikel.Pdf.Pdf

Cao, W., Fang, Z., Hou, G., Han, M., Xu, X., Dong, J., \& Zheng, J. (2020). The psychological impact of the COVID19 epidemic on college students in China. Psychiatry Research 112934

Dadang Darmawan, Deni Miharja, dkk ,Sikap Keberagamaan Masyarakat Muslim Menghadapi Covid 19 https://journal.uinsgd.ac.id/index.php/Religious/article/view/8596/pdf, diakses tanggal 20-92020

Fernandes, N. (2020). Economic effects of coronavirus outbreak (COVID 19) on the world economy. Available at SSRN 3557504

Gössling, S., Scott, D., \& Hall, C. M. (2020). Pandemics, tourism and global change: a rapid assessment of COVID 19. Journal of Sustainable Tourism

Intruksi Presiden Nomor 6 Tahun 2020 tentang Peningkatan Disipilin dan Penegakan Hukum Protokol Kesehatan

Intruksi Presiden Nomor 6 Tahun 2020 tentang Peningkatan Disipilin dan Penegakan Hukum Protokol Kesehatan Dalam Pencegahan dan Pengendalian Corona Virus Disease

Keputusan Presiden RI No.7 Tahun 2020,tentang Gugus Tugas Percepatan Penanganan COVID-19 
Keputusan Presiden RI No.9 Tahun 2020. Gugus Tugas Percepatan Penanganan COVID-19

Muhammad Fatoni, Tribunjogja.com, (2020), Peta Sebaran Kasus Baru Covid-19 hingga Sabtu 12 September 2020 Data Rinci di 34 Provinsi, https://jogja.tribunnews.com/2020/09/12/petasebaran-kasus-baru-covid-19-hingga-sabtu-12-september-2020-pagi-ini-data-rinci-di-34provinsi.

Maharani C, dkk (2020) Pemeriksaan Iva Deteksi Dini Lesi Pra Kanker Di Masa Pandemi Covid19 Pada Masyarakat Mendalo Indah, Jambi, https://onlinejournal.unja.ac.id/medic/article/view/13475/11292

Notoatmodjo, S. (2012). Metodologi Penelitian Kesehatan. Jakarta: Rineka Cipta

Sugiyono, (2019), Metode Penelitian Kuantitatif kualitatif R\&D, Alfabeta, Bandung

Suharsimi-Arikunto, S. (2010). Prosedur Penelitian Suatu Pendekatan Praktek. Rineka Cipta: Jakarta

Trubus Rahadiansyah, (2020), Analis: Peran Masyarakat Penting dalam Aturan Atasi Covid-19 https://republika.co.id/berita/q80mar349/analis-peran-masyarakat-penting-dalam-aturan-atasicovid19

Undang-Undang Republik Indonesia No 36 Tahun 2009 Tentang Kesehatan

Undang-Undang Republik Indonesia Nomor 24 Tahun 2007 Tentang Penanggulangan Bencana Surat Edaran Menteri Desa, PDT, dan Transmigrasi Nomor 8 Tahun 2020 tentang Desa Tanggap Covid-19 dan Penegasan Padat Karya Tunai Desa

Keputusan Presiden RI No.7 Tahun (2020) tentang Gugus Tugas Percepatan Penanganan COVID-19.

Mambang., Sari, A., \& Hariyati, I. (2012). Hubungan Pengetahuan dengan Peran Orang Tua dalam Mencegah Terjadinya Resiko Kehamilan diusia Remaja Pada Siswa SMA Swasta X Banjarmasin. http://akbidsarimulia.ac.id. peran/orang/tua.pdf. Diakses tanggal 15 Januari 2016

Subhan Muhith, Dianita Ekawati, Santi Rosalina, Chairil Zaman,2021 Analisis Kepatuhan Penerapan Protokol Kesehatan Covid-19 Jurnal Áisyiyah Medika Vol 6 No 2 Issn Online 2622-3872, Issn Cetak 2614-2791, Palembang.Ac.Id/Index.Php/Jam/Article/View/651

Rosali M, (2021), Evaluasi Pelaksanaan Program Deteksi Dini Kanker Serviks Dengan Metode Inspeksi Visual Asam Asetat (IVA) Di Puskesmas Guguk Panjang Kota Bukittinggi Tahun 2021. https://repository.fdk.ac.id/journal/detail/6412/evaluasi-pelaksanaanprogram-deteksi-dini-kanker-serviks-dengan-metode-inspeksi-visual-asam-asetat-iva-dipuskesmas-guguk-panjang-kota-bukittinggi-tahun-2021

Muhammad Fatoni, Tribunjogja.com, judul Peta Sebaran Kasus Baru Covid-19 hingga Sabtu 12 September 2020 Pagi Ini, Data Rinci di 34 Provinsi, https://jogja.tribunnews.com/2020/09/12/peta-sebaran-kasus-baru-covid-19-hingga-sabtu-12september-2020-pagi-ini-data-rinci-di-34-provinsi?page $=2$

Nurjasmi E (2020), Situasi Pelayanan Kebidanan Pada Masa Pandemi Covid - 19 Dan Memasuki Era New-Normal, https://Www.Ibi.Or.Id/Media/Materi Webinar Ibi - Usaid Jalin Covid19/Seri 5 10 Juni 2020/Pdf 1 Emi 10 Juni Usaid

WHO. (2020). Coronavirus disease (COVID-19) advice for the public: Advocacy. Www.Who.Int. https://www.who.int/emergencies/diseases/novel-coronavirus-2019/advice-for-public/healthyparenting

WHO, (2020) Mempertahankan layanan kesehatan esensial: panduan operasional untuk konteks COVID-19 https://www.who.int/docs/default-source/searo/indonesia/covid19/maintainingessential-health-services---ind.pdf

Yulia R, dkk, Dampak Pandemi Covid-19 Pada Layanan Kesehatan Ibu Dan Anak (Kia) Di Kota Depok,: Jurnal Ilmu Kesehatan Masyarakat Vol. 17, No. 2, September 2021Issn: 2684-7035; Doi: 10.19184/Ikesma.V\%Vi\%I.25067, Http;//Jurnal.Unej.Ac.Id 